\title{
The Russian Borrowings and their Role in the Formation of Microtoponyms in the Azerbaijan Dialects
}

\author{
Mirzayev E.S. \\ Faculty of Humanity Siences \\ Department of Azerbaijan language and literature and their teaching methodology \\ Lenkoran State University \\ Lenkoran, Azerbaijan \\ mirzayev_or@mail.ru
}

\begin{abstract}
The article is devoted to linguistic analysis of Russian borrowings, which was observed in Azerbaijani dialects and was selected with special care. The purpose of the research here is to investigate the forms of assimilation of Russian acquisitions within the context of language regularities and to make a substantive comparison with their final variants based on their initial variants. Comparative and typological-reconciliation methods were used during the study. The scientific novelty of the research is that for the first time Russian acquisitions are involved in the dialogue on the basis of the materials of the Azerbaijani language at the dialect level. In conclusion, it is noted that the Russian language that once lived on the territory of Azerbaijan has become a universal word and gained citizenship.
\end{abstract}

Keywords-Azerbaijani; Russian dialect; dialect; microtoponym; areal.

\section{INTRODUCTION}

A significant part of the vocabulary of the Azerbaijani language contains words with Russian origin, which have been the subject of various aspects of linguistic research till now.

The main reason for the influence of Russian words into Azerbaijani language stems from the socio-political and cultural relations between the Azerbaijani and Russian peoples since the early nineteenth century, when northern Azerbaijan joined Russia. The use of the Russian language as a common communication means among all the Soviet peoples during the post-Soviet period further enhanced its influence on the Azerbaijani language.

As a result, many Russian borrowings in the household, agricultural, scientific and technical fields enriched the vocabulary of the Azerbaijani language. At present, political, economic and cultural ties between the two neighboring nations are developing in all directions on increasing line, and there are many opportunities for learning Russian in various scientific and educational institutions of Azerbaijan.

The Russian words and borrowings in Azerbaijani linguistics have been extensively studied since the 50s of the XX century in both general linguistic works, textbooks and a number of monographical studies $[3 ; 4 ; 5 ; 6 ; 10 ;]$.
However, it should be noted that in all of these studies, the russisms used only in Azerbaijani literary language were mentioned. Although our research suggests that, along with the literary language, the dialect lexis of the Azerbaijani language also includes russisms in various fields, and till now no major research has been conducted in their study.

As a result of our research on the Azerbaijani language in the Lankaran and Mugan group, we have identified some russisms in the region, especially in the areas of fishing, agriculture, and forestry. It should be noted that a significant portion of these borrowings are sounded by Russian folk dialects and parallel variants are found in Don, Novosibirsk, and Astrakhan dialects.

\section{RESEARCH METHODOLOGY}

According to some sources, the first arrival of Russian speaking population to Azerbaijan dates back to the 1930s. M.Valili (Baharli) points out that the first arrival of Russians and Ukrainians was in 1837: "These emigrants came from the southern provinces of Ukraine, along the Itil and the central provinces of Velicorussia".

The author notes that Velicorussian contains from malacan, dukhobor, baptist, subbotnik (community work day) and other sectarians and they were exiled by the Tsarist government and their agents [7, 65].

According to sources, L.Guliyeva writes that the first Russian immigrants from the southern provinces of Russia (Tambov, Voronezh, Kharkov, Astrakhan, etc.) come to Azerbaijan in the 1930s [Lala, 18]. The transfer policy has covered almost all regions of Azerbaijan in a short time. In particular, by the end of the XIX century, the number of these settlements was about 15 in the Lankaran region, and about 40 in the early XX century in the Mugan region [1, 351-355; 8, 18-19].

Certainly, the Russian peasants living in Azerbaijan come to these places in some sense. They took into account the conditions of these locations and brought traditional tools. 
balber//balbur//balbir//balbirks <balber in Don dialect of According to sources, G.Javadov writes that the large netting types like "venter" and "seine" used by the Russian peasants in Lankaran were already used by the local population in the late XIX and early XX centuries [2, 195-197].

Studies show that the spreading range of Russian borrowings in Azerbaijani dialects varies according to the geographical location of individual regions. For example, in the coastline of the Caspian Sea areas of the Lankaran lowlands, the russisms associated with the fishing area attract attention. For example:

ilis//iliska//iqliçka//iqliçka - is a tree tool for weaving and repairing fish nets. Approximately $20-25 \mathrm{~cm}$ long, there are cuts on both sides to spin threads used for knitting nets. In the same meaning глица//гличка//игличка//игла//иглица is used in the Don and Novosibirski dialects $[13,152 ; 11,198]$.

In the V.I.Dal's dictionary иглица word is shown as follows: "needle for knitting nets, usually wooden, with a notch for winding threads" [9, II v., 6]; naboynik - 10-15 m iron trench tool for For fixing nets to the land in the sea. V.Dal writes in Astrakhan dialect this word is used like набойник connected with the word stuff (набивать, набить) etymologically: "tin-plate with an iron pipe at the end, for driving chipchiks into the seabed" [9, v. II, 378].

jivotnoy - It is a narrow net that has numerous hooks for small fish that is caught and thrown into the sea. живёточка//животочка//животь is used in the meaning "small live fish used as bait for catching large fish, live bait fish" in the Novosibirsk dialects of Russian language [14, 151-152];

zaboy is the name of a part set up at sea to guide the fish into a narrow net called "catol". It is observed in close semantic shades, in the Don dialects of Russian language in the variant of забой//забойка $[17,163]$;

valaquş//valakuş < in the Don dialects of Russian language as волокуша//волокушка//волокушник - "small net", "master of net" [17, 84];

veşla//veşala < in the Don dialect of Russian language as вешала (hung) "device for drying nets" [15, 63]; fish.

çəkuşkə//çakuşka is a tree tool for shooting large sturgeon

In the Don dialect of the Russian language it has the same meaning in the form of а чакушка [16, III v., 188]; qurzink an iron-tip tree tool for submerging some fish nets in the sea. The parallel version, which is closely related to this meaning, is as follows in Russian folklore:

грузилка - "fork, used fishing tackle and its direction under the ice" $(18,167)$;

qormişka//qorma//korma < in the Don dialect of Russian language is a "flooring at the stern of the boat for sitting" [17, 245];
Russian language// balbera // balberka "fishing net float" [17, 27].

V.I.Dal's explanation corresponds to the parallel form in the dialects of Azerbaijani language. Thus, the word чипчикь is characteristic to the Caspian Sea dialects of the Lankaran lowland, which is defined by V.I.Dal in the dialects of the Caspian Sea and which is semantically shown as follows: "small, sharp-pointed wooden tool used for fastening nets and other tools to the sea bottom". About 1 meter long, this sharppointed wooden instrument is used to show the type of netting "katol" in local dialect which built-up and fastens to the sea bottom; çəkuşkal/çakuşka is a tree tool for shooting large sturgeon fish.

In the Don dialect of the Russian language it has the same meaning in the form of чакушка [12, v. III, 188]; qurzinka is an iron tip tool for submerging some fish nets in the sea. In Russian dialects, it is used $\mathrm{n}$ the same meaning in грузилка form $[14,167]$.

There are also russisms dealing with forestry in settlements around forest areas. For example, dilankə (in the Jalilabad, Masalli, Yardimli dialects of Azerbaijan language) is a "chopped, cut forest area", "a forest area for chopping and cutting."

V.I.Dal has explained this by referring to the word "to break up, disassemble, break down, dismantle, break off", делянка as follows: "forest area allocated for the next felling" [11, I v., 511]. In the dictionary of E.M.Murzaev, the делянка (plot) is given in the following meanings: "land suitable for farming" "forest plot prepared for arable land, cleared of trees and shrubs" and "cutting area" and etymological explanation is Slavic origin (divide, limit, allotment, inheritance, allot, section, division is given for comparison) and in this semantic row - in Russian dialects it is linked with the such words like дел (work) "share", "part of the land allotment", "plot of grassland obtained during the annual division of meadows", "plot of land in which each owner of this community has one strip", "measure of land, different in 800 square saplings, in Bulgarian language "part","department","share", in Polish language dzial "share","portion","part", "border", in Serbian-Croatian language dio//djel "part" [12, 175-183].

The word делянка word is used in Russian folk dialects. In the "Dictionary of Russian folk dialects" work делянка has 18 meanings; in this line the fourth meaning "deforestation" is relevant in the registered meaning of the dialects of Azerbaijan language [14, 348]. In the V.I.Dal's dictionary the word делянка is explained as follows: "forest plot allocated for the next felling" [9, p., 511].

In the Russian literary language, the word борозда "furrow" (the trail made by plow and other tool in the land") is used; this word in baraza variant takes place in the dialects of Mugan group of the Azerbaijani language in the line of agricultural words $[19,18]$ 
One of the more striking features is the etymologically Turkic origin of some of the words that have been spoken by the Russian-speaking population of the region and are now being used in local dialects. For example, chalbash//chalbashka in Russian language of Astrakhan and Novosibirsk dialects (can be compared: çabak "small fish" in Turkic monuments, çapaq in Azerbaijani language, çabak//çoboқ in Uzbek language), is the "small sturgeon" - up to twelve kilograms of chalbash, and all one fish - sturgeon [11, IV v., 581; 14, 578]; chakushka "a tree tool for shooting large sturgeon fish" > чакушка//чекушка//чакуха in Russian language of Novosibirsk dialects (can be compared with чекуша which is Turkic origin and with the word чӓкич $[10,17])$ "wooden beater", in Don dialects чакуша// чакушка "stick", "smash and stun fish" [14, 578; 16, III v., 188].

Speaking about Russian borrowings of Turkish origin, M.Tekleli united a group of words under the heading "Reflixive borrowings": "This event is supposed to return of ancient Turkisms that have been transmitted to the Russian language. An interesting and noteworthy issue is that a number of words that is admitted as Russian borrowings, such as йогурт (yoghurt), киоск (kiosk), ярлык (tick), шапка (hat), чулок (stocking), барак (sheet), шайка (sack), чемодан (suitcase), наждак (emery), тариф (tariff), монета (coin), каторга (hard labor), товар (goods), болван (doodle), адмирал (admiral), кефир (kefir), лапша (noodles), вишня (cherry), сазан (çarp), севрюга (seaweed), хомут (hamut), and others are true Turkish words. In fact, this should be regarded as an return to our language "[6, 62]. This view reaffirms that some of the Turkism seen in parallel forms in Azerbaijani and Russian languages has also passed through the language of the Russian-speaking population.

Appeals of Russian origin have spread among the microtoponyms of Azerbaijan. However, it should be noted that these names can be followed in a scattered, retail form, rather than in a specific range. These recorded microtoponyms can be grouped as follows:

1. Microtoponyms formed on the basis of special names: The geographical names containing "Russian" etnonyms and other personal names of Russian origin are observed in this line. It is noted that the phonetics of Azerbaijani language has such a feature that at the beginning of the words with $r$ phoneme, as a rule, i or o vowels are added.

From this point of view, Rus (Russian) name is pronounced in the form of Oruz in the local dialects, which is reflected among microtoponym forms. For example:

Orus Bridge (Amirturbe village in Masally district) orus>rus "Russian" + мост "bridge" - körpü in Azerbaijani language; Orus $a \breve{g} l$ (Kochekli village in Masally district) orus> rus "Russian" + ăg in Azerbaijani language "it is a water place surrounded by swampy vegetation and swamps"; Orus göli (Zopun village in Jalilabad district) - orus>rus "Russian" + göl "lake" in Azerbaijani language; Motvey keçalatı
(Fatullakishlak village in Jalilabad district) Mətvey > Matthew "person name" + keçalat//keçələt "passage in the streams and rivers" in Azerbaijani language;

2. Microtoponyms formed on the basis of common words of Russian origin: the words formed on the basis of the word dilankə (делянка "deforestation", "forest area allocated for the next felling in Russian dialects); f.e., Maslahat dilankasi, Mammatkarim dilankasi, Hazar dilankasi (Amirturbe village in Masally district), Paşa dilankasi, Illi dilankasi, Orus dilankasi - orus> rus "Russian" (Yolagadz village in Masally district), Miseyib// Museyib dilenkesi, Meshedmemish dilenkesi (Zopun village Jalilabad district),

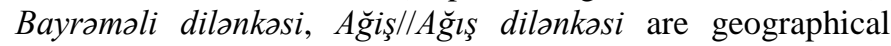
names, especially microtoponyms formed on the basis of antrotoponyms; the words formed on the basis of word ventir (in Russian language вентерь "pouch-shaped netting type used in seas and rivers"); For example: Cavad ventir quran (Khirmindali village in Masally) - in literal meaning: "The place where person named Javad built the netting вентерь".

\section{RESULTS}

The results of the study can be summarized as follows:

- The russisms are also partially reinforced in the Azerbaijani literary language along with dialect vocabulary, and their distribution across different areas varies according to the range. In our opinion, this can be attributed to the geographical location of those areas where historically having being settled and compact lived Russian-speaking population.

- As a result of our research, we have discovered more than 50 russisms in the lexicon of the Lankaran and Mugan group of Azerbaijani languages, many of which are related to fishing. We have identified 17 words used in Russian dialects on the basis of materials of various compilation dictionaries of Russian folk dialects, including the dictionary of V.I. Dal's dictionary "The explanatory dictionary of living Velikorussian language". These words are mainly characteristic of Don, Novosibirsk, Astrakhan dialects of Russian language.

- The Russian appeals to some extent penetrated the Azerbaijani microtoponymics and it is possible to observe them inside the open-and-shut areal.

\section{CONCLUSION}

At the end, it is important to note that the areas of the Azerbaijan Republic that we are currently surveying are almost no longer areas where the Russian-speaking population once lived.

They voluntarily returned to their homeland because of the collapse of the USSR in the 1990s, the socio-political processes in the South Caucasus, and other some reasons. But for nearly 150 years, they live in friendly neighborhoods with the local population, and in addition to leaving a rich heritage in their culture and ethnography, they maintain some traces of their local artifacts and geographical names. 
[10] Kubanova L.A. Turkisms in the dialect vocabulary of the Russian language (according to the "Explanatory Dictionary of the Living Great Russian Language” by V.I.Dal). Candidate's thesis. Moscow. 1968

[1] Cavadov G. Minority peoples and national minorities of Azerbaijan (in Azerbaijani language). Baku, Science Publishing House. 2000

[2] Cavadov G. Talishlar (in Azerbaijani language). Baku, Science Publishing House. 2004

[3] Jafarov S. Contemporary Azerbaijani language (in Azerbaijani language). Baku, Maarif Publishing House. 1982

[4] Guliyeva H. Calque means from Russian into Azerbaijani. Abstract of $\mathrm{PhD}$ dis. (in Azerbaijani language). Baku. 1990

[5] Mammadli N. Borrowings terms (in Azerbaijani language). Baku, Science Publishing House. 1997

[6] Tekleli M. Turkic words in Russian language (in Azerbaijani language). Baku, Nurlar Publishing House. 2006

[7] Aliyev G. The Russian borrowings in the Azerbaijani language. Abstract of Ph.D diss. Moscow. 1973

[8] Velili M. (Baharli). Azerbaijan: physico-geographical, ethnographic and economical essay (in Azerbaijani language). Baku. 1993

[9] Guliyeva L. Russian toponymy of Azerbaijan: history and modernity. Baku. 2010

[11] Dal V.I. The explanatory dictionary of living Velikorussian language: In 4 volumes. V. I and II, Moscow, "Russian Language". 1999

[12] Murzaev E.M. Dictionary of folk geographic terms. Moscow, Thought Publishing House. 1984

[13] Novruzova S. Methods of transferring prefixal Russian-international terms to the Azerbaijani language. Candidate's thesis. Baku. 1990

[14] Dictionary of Russian dialects of the Novosibirsk region. Novosibirsk, Nauk. 1979

[15] Dictionary of Russian Don dialects. In 3 volumes, T. I, Rostov, Publishing house of the Rostov University. 1975

[16] Dictionary of Russian Don dialects. In 3 v., V. III, Rostov, Rostov University. 1976

[17] Dictionary of Russian Don dialects. In 2 v, V. I, Rostov, Rostov University. 1991

[18] Alexsandr S. Kuznetsov. Russian Professor's meeting. Russian Journal of Physical Education and Sport. 2019, 14(1), pp. 17-22. DOI: 10.14526/2070-4798-2019-14-1-18-24

[19] Dictionary of Russian folk dialects. 7 issue, Leningrad. 1972 